\title{
PROSPECTS OF EUTHANASIA LEGAL REGULATION IN UKRAINE
}

10.36740/WLek202010135

\author{
Tetiana A. Pavlenko ${ }^{1}$, Tetiana Ye. Dunaieva ${ }^{2}$, Marina Yu. Valuiska ${ }^{3}$ \\ ${ }^{1}$ H. S. SCOVORODA KHARKIV NATIONAL PEDAGOGICAL UNIVERSITY, KHARKIV, UKRAINE \\ ${ }^{2}$ ACADEMICIAN STASHIS SCIENTIFIC RESEARCH INSTITUTE FOR THE STUDY OF CRIME PROBLEMS, NATIONAL ACADEMY OF LAW SCIENCES OF UKRAINE, \\ KHARKIV, UKRAINE \\ ${ }^{3}$ YAROSLAV MUDRYI NATIONAL LAW UNIVERSITY, KHARKIV, UKRAINE
}

\begin{abstract}
The aim of this article is to explore the ways of euthanasia regulation and to propose the most effective one.

Materials and methods: The authors of the article used the methods of analysis and synthesis, a comparative legal method. The scientific literature is evaluated and analyzed along with the experience of European countries, data of Ukrainian and international organizations and the results of scientific researches.

Conclusions: the understanding of euthanasia should be reviewed in terms of the possibility in exceptional cases of its executing for terminally ill person. This is an inherent human right. However, it is established that the right to dispose of his life belongs exclusively to the bearer of this right and it cannot be delegated.
\end{abstract}

KEY WORDS: euthanasia, death with dignity, right to die, patients' rights, terminally ill patients, palliative care, compassion

Wiad Lek. 2020;73(10):2289-2294

\section{INTRODUCTION}

In modern theory of criminal law there is a hot debate not only on understanding of the euthanasia concept, but also on its typologization: voluntary and coercive - depending on the consent of the individual; active and passive - depending on the nature of the behavior (action or inactivity).

The problem of euthanasia is a problem of choice (moral choice of society, professional and ethical choice of doctor, personal choice of the individual). This choice can and should be made on the basis of biological ethics. However, ethical standards are not endowed with an effective implementation mechanism. The very right is a measure of social compromise and a mechanism for ensuring public safety.

The right of the patient to freely manage his life includes the right to terminate his life (i.e., to commit suicide) and the right to terminate life with the help of others.

\section{MATERIALS AND METHODS}

The study analyzed the experience of European and other countries. In addition, in this study we used data from Ukrainian and international organizations, findings of scientists and decisions of the European Court of Human Rights.

The legislation of Ukraine, international acts, legislation of the European and other countries, decisions of the European Court of Human Rights, materials from the Unified State Register of Judgments were used. Methodological basis of this research was the set of general and special scientific methods. The use of comparative analysis method made it possible to investigate, analyze and identify the problem of euthanasia regulation in foreign countries. The dialectical method contributed to the study of the nature and features of euthanasia. The dogmatic method was used in the analysis of the legislation provisions on the liability for euthanasia execution.

\section{REVIEW}

The study examined international legal acts and decisions of the European Court of Human Rights in the Cases of "Pretty v. The United Kingdom" [1], "Sanles Sanles v. Spain" [2], "Gross v. Spain Switzerland" [3], "Afiri and Biddarri v. France" [4].

Having analyzed the provisions of the Convention for the Protection of Human Rights and Fundamental Freedoms, adopted on 4 November 1950, and the practices of their application, we have concluded that the problem of euthanasia has not been resolved at that time in international law. The European Court of Human Rights has sought to clarify this in the Case of "Pretty v. The United Kingdom" (29 April 2002) where he noted that Art. 2 of the Convention cannot be construed as conferring the right to die or to receive assistance from another person in causing his own death. However, the ECtHR did not recognize that euthanasia was a violation of the right to life and declined to comment on the legalization of eu- 
thanasia in a number of European countries, indirectly recognizing each country's ability to regulate euthanasia at the national law level [3]. In the case of "Sanles Sanles v. Spain" (26 October 2000) on granting the right to a decent life and a decent death, as well as non-interference with one's own personal life by prohibiting suicide assisted by a doctor, decided on the inadmissibility of the claims made [1]. This ECtHR position was revised in case "Gross v. Switzerland" (30 September 2014), in which the Court held by a majority vote that there had been a violation of Art. 8 of the European Convention. However, in the case of "Afiri and Biddarri v. France" (23 January 2018) on refusal to provide life support for a 14-year-old girl who was in a vegetative state after a severe cardiovascular deficiency, the ECtHR found the parents' claims unjustified, noting that the current national legislation of France complies with Art. 2 of the Convention [4].

According to the Venice Declaration on Terminal Status, adopted by the 35th World Medical Assembly (WMA) in October 1983, a physician in the course of treatment is obliged to alleviate the patient's suffering whenever possible acting in his best interests. It is considered that doctor does not continue the suffering of the dying person, stopping at his request, and if the patient is unconscious - at the request of relatives, treatment that can only delay the onset of the inevitable end. However, refusal of treatment, according to the 1983 Declaration, does not relieve the physician of the obligation to assist the dying person by prescribing drugs for the relief of suffering [5].

The Doctor's Declaration of Euthanasia and Suicide, adopted in October 2019 in Tbilisi at the 70th WMA, states that euthanasia as an act of deliberately depriving a patient of his life, even at the request of the patient himself or on his relatives' request, is unethical. This does not exclude the need for the doctor to respect the patient's desire not to interfere with the natural process of dying in the terminal phase of the disease. The WMA reaffirms its strong commitment to the principles of medical ethics and the highest respect for human life. Therefore, the WMA is firmly against euthanasia and physician-assisted suicide. However, a doctor who respects a patient's fundamental right to refuse medical treatment, does not act unethically in refusing unwanted help even if respect for such a desire leads to the death of the patient [6].

Thus, both the Venice and Madrid declarations of the WMA allow for a passive form of euthanasia, namely, when the doctor does not use any measures to prolong the life of the patient but only uses painkillers.

\section{DISCUSSION}

The current stage of Ukrainian society development is characterized by two opposing tendencies: the commitment to the democratic standard based on the rule of law - on the one hand, and the existence of legal illiteracy, old misconceptions and remaining legal nihilism - on the other. [7, p. 193]. The natural, inalienable human right is the right to life, which also implies the existence of a "right to a de- cent death". This problem provokes eternal debate among philosophers, sociologists, lawyers and doctors. There are two diametrically opposite points of view regarding the possibility of a persons to terminate their lives freely (it is clear that suicide is not covered): on the one side there are supporters of the "right to a decent death", on the other the opponents of premature death.

Oddly enough, some doctors are among the supporters of legally authorized euthanasia. For example, according to a survey commissioned by the Royal College of Medicine (UK) in 2006 and 2014, when asked whether respondents (college members, GPs) support changes to the law to grant permission to help endure life of the sick person, the following answers was given: the majority of respondents (3858 persons - 58\%) said no, 2168 persons (32\%) answered yes, $10 \%$ answered yes, but not by doctors. Particularly interesting is the fact that among those doctors who answered "no", the majority were representatives of palliative practice ( $85 \%, 415$ responses) [8].

There are also supporters of euthanasia among lawyers. They often justify their position by referring to natural, inalienable, constitutional subjective rights, fundamental rights and human freedoms. The constitutional establishment of the right to life logically means the legal fixation of the human right to death. The right to life belongs to the category of personal human rights, that is why it is implemented individually and independently, regardless of the others' will.

Peter Singer, an advocate of euthanasia, notes that the most important aspect of the right to life is the ability to choose to continue living or not. A person values the right to live only when he wants to live [9, p. 218-219].

Philip Nitschke argues that anyone, including the terminally ill persons and people with depression, should be eligible for help to terminate their lives [10]. Contrary to that according to Richard Huxtable, who while raising the urgent issue of depression and "dying assistance" notes that discussing the possibility of such assistance demonstrates a slippery path and raises even more questions about establishment of the limits of such "help", especially since it concerns depressed persons [11].

A.F. Connie believed that voluntary active euthanasia could only be used in exceptional circumstances if the following conditions were met: a) the patient's conscious and persistent request; $b$ ) the impossibility of alleviating the patient's suffering by known means; c) the unquestionable demonstration of the impossibility of saving the life established and approved by the College of Doctors with obligatory unanimity; d) prior notification to the prosecutor's office and presence of the prosecutor's office staff $[12$, p. 10].

Sarah Elizabeth Mathieson, being a supporter of legislative euthanasia, stresses that this will not cause us to "indulge" euthanasia for any reason, nor does it oblige society to accept involuntary euthanasia the day after such anchoring. The researcher notes that a person should be given the right to make his/her own decisions, the possibility to use euthanasia should be one of these options [13]. 
Summarizing the arguments of the euthanasia use supporters the following could be stated: 1) the right to life also contains the right to death, which is the ability of a person to consciously and voluntarily at a certain time to terminate his life in a chosen and accessible way; 2) denying a person's right to die the state and society thereby restricts his freedom; 3 ) the use of euthanasia complies with the principle of humanism; 4) refusal of euthanasia can be considered as the use of torture, violence, cruelty and humiliation of human dignity; 5) failure to apply euthanasia in some cases violates the patient's right to respect for dignity; 6) a terminally ill person could become an organ donor for transplant patients; 7) it is economically feasible to conserve the funds spent to sustain the lives of terminally ill patients, who do not wish to prolong their lives. These funds could be used to treat patients who have a chance of recovery; 8) euthanasia is an action of a person in a state of extreme need. An extreme need according to domestic criminal law is a circumstance that excludes crime. Therefore, euthanasia should be recognized as an additional circumstance that excludes crime [14, p. 101-102].

Turning to the experience of foreign countries it should be noted that the introduction of euthanasia is widely discussed in many of them.

For example, a public opinion poll conducted to investigate the possibility of euthanasia legalization, executed by scientists in the United Kingdom, France, the United States, and Japan, found that $71 \%$ of respondents were ready to approve euthanasia in certain circumstances, $76 \%$ of respondents in France has called for the abolition of a law prohibiting euthanasia. Americans in the six to one ratio support the right of the patient to decide whether to disconnect life-saving equipment. $81 \%$ of the surveyed residents of Japan agree that in the state of complete absence of hope for a cure it will be admissible to terminate the patient's life and shut down his/ her life-support system [15, p. 73].

Nowadays, the judicial practice of several states (Sweden, Lithuania, Germany, the USA, etc.) shows the approval of the euthanasia methods use. For example, in the US a terminally ill paralyzed woman, while conscious, required to shut off the respiratory apparatus that supported her life. Despite the doctors' protests the court granted her request, stating that it would be cruel to preserve an existence that is overflowing with pain [15, p. 70].

Voluntary euthanasia is also allowed in Australia. The receipt or cancellation of medical treatment currently occurs in Australia under different circumstances and rules [16, p. 4]. First, the Medical Council of Australia and the Society for Palliative Medicine of Australia and New Zealand (ANZSPM) state that it is good medical practice when doctors involved are sharing understanding that they have no obligation to try to prolong life at any cost. However, they have a duty to know when not to initiate and when to stop attempts to prolong life, while ensuring that their patients receive appropriate relief from suffering. With the assumption that patients have the right to refuse medical treatment or to request cancellation of treatment that has started [17].
The first country to legalize euthanasia was Netherlands. Such a decision has reasons and its adoption was followed by a rather lengthy (about 20 years) and heated debate both in society and among political elites.

By 1998, according to research by Rotterdam University of Eraum, voluntary euthanasia was supported by $92 \%$ of the Dutch population. Despite the above arguments of a religious nature, the majority of believers, including $96 \%$ of Catholics, were in favor of the possible termination of the patient's life by their own free will.

Although there once been raised an issue about the existence of a culture of death caused by the number of early deaths of patients, The Royal Medical Association - the Koninklijke Nederlandsche tot beverdering der Geneeskunst (KNMG) has however reiterated that the law of life termination should be an exception and not a rule, and that this procedure will never become the standard [18], although a number of physicians do not consider euthanasia to be an exclusive measure requiring social control over it [19, p. 197-216].

As Jurriaan De Haan points out, the attitude to the issue of euthanasia in Netherlands is based on two factors: firstly, the decision must be voluntary and thoughtful, and secondly, the patient is suffering unbearably and hopelessly. Thus, euthanasia is morally justified with due respect for the principle of autonomy [20].

Opponents of euthanasia legalization for the most part are quite categorical. They say that this idea has no ethical grounds. Because a doctor, who use euthanasia, violates the most important humanistic principle of medicine known since ancient times, because every doctor must fight for the life of the patient until the last breath.

Joseph Pakhu notes that euthanasia is unethical because it means deprivation of a patient's life. Murder can never be justified for whatever reason it is committed [21].

Euthanasia affects the interests of healthy people too, who can easily (with the "help" of corrupt physicians) be turned into hopeless patients. The arguments presented not devoid of logic and indeed, if the legal framework assumes ambiguous interpretations, the discretionary powers of doctors and foster carers, the legalization of euthanasia can be a violation of the right to life and a "brake" on the way of searching for new effective treatments.

L. Misyura and M. Lysenkov are quite categorical against euthanasia, noting that its use will have a lot of negative consequences. These include demoralization of society, criminalization of medicine, forced euthanasia (for example, to save money for the maintenance of lonely elderly people, people with disabilities, patients with cancer and AIDS, etc.), suspension of medical science development, dishonesty of medical personnel in carrying out their medical duties. etc. [14, p. 102-103].

It should be noted that there is a problem of medical error, and such a problem is urgent not only for Ukraine. High level of medical errors made by officially highly qualified medical personnel is related to the stability of the attestation system [22]. At the same time, a qualification category does not mean that the doctor is subject 
to responsibility. There is no mechanism in Ukraine to prosecute physician for the incompetent medical care and medication [23]. Moreover, it is extremely difficult to prove such a mistake, and the causes and mechanisms of such errors are not identified at the state level, they are not even discussed, which makes it impossible to outline measures to prevent them or reduce their frequency and danger [24].

Analyzing the above arguments, we can point out that the concept of "incurable" is a fairly conventional notion that it largely depends on the money and capabilities of the patient and the doctor.

As for the diagnostic errors, as we have already noted, this is a good argument since any prognosis is always only probable (it largely depends on the patient's internal attitude to the disease, doctor's qualifications, trust in the doctor, desire to be cured, etc.).

On the contrary, more and more recently euthanasia opponents have been saying that there is a need for an adequate care for the terminally ill. Palliative care with its "right" ideology, which aims to achieve the best quality of life for patients and their families, is an alternative to euthanasia. Therefore, it is necessary to develop, approve and fund State programs for the development of palliative care and hospice care, to establish a National Coordination Council for palliative care and hospice care, to create a legal framework for the legal regulation of palliative care, to establish a system of state control over the quality of palliative care and palliative care patients in the palliative care process through accreditation and licensing of palliative care facilities [25]. Note that it is necessary to distinguish between palliative sedation and terminal sedation. As Boudreau JD, Somerville M. point out, "palliative sedation" is the only sensible way to control pain and suffering and is used for this purpose. This is not euthanasia. "Terminal sedation" refers to a situation where the death of a patient is not imminent, and the patient calms down with the primary intention of accelerating his death. This is euthanasia [26]. In this context, the issue of "persistent deep sedation" ("palliative sedation") in pediatrics for terminally ill children is relevant. For example, Swiss scientists argue that in pediatrics permanent deep sedation is a morally preferable alternative to euthanasia because it can meet the same patient needs as euthanasia and in addition, children lack capacity and experience in decision-making of such kind[27].

Evan Goliger and Wesley Eli with colleagues note that it is unethical to terminate a patient's life in the context of patient care at the end of his life, because such actions contradict what they consider to be the "Moral grounds of medicine": the invaluable value of the human personality. Medicine derives its moral greatness from respect for the value of each person, a value that exceeds circumstances or preferences. This value comes from a person's status as a reasonable person capable of making a moral choice [28].

We can sum up that the arguments of euthanasia opponents are made from the standpoint of a third-party "observer" of personal attitudes, moral convictions and analysis of the mechanism of activity of legal mechanisms and health systems known to them. Proponents of euthanasia, when making assertions-claims, appeal to the subjective (as they imagine it) patient's experiences and rights, victims of the problem, operating categories of "dignity", "quality of life" and "patient's benefit". Euthanasia advocates claim that life is no longer a value in itself, but a life of a certain quality. If the quality of life does not meet the needs of the individual, then it (life) may not have value for individual and therefore may be terminated at its will.

At the same time, one cannot ignore the situation where the lack of harmony in the legislation of some European and American countries has led to some adverse effects, such as "death tourism", the phenomenon when residents of one country where euthanasia is banned travel to another countries where it is allowed and where doctors can euthanize. To avoid this, it is necessary to achieve some degree of harmonization of legislation or to set an appropriate limit in the laws that have legalized euthanasia. However, time will show if that could be achieved [29, p. 162]. Switzerland has become a mecca for foreign "euthanasia tourists". The most popular among tourists is Dignitas company. There are various programs for such tourists and their average cost is 4,000 euros. Most patients come from Germany, United Kingdom, France and Italy [30]. "Euthanasia tourism" can be linked to "medical tourism", another phenomenon that has led to advances in medical technology, the development of travel opportunities and the globalization of health care. These factors are the basis for facilitating the movement of consumers across the border for medical assistance [31].

It is difficult to give a clear answer to the question of euthanasia prevalence in Ukraine and to provide some specific statistics. There were a number of conferences somehow devoted to euthanasia in Ukraine, research conducted by the O. Razumkov Ukrainian Center for Economic and Political Studies on the use of euthanasia in Ukraine, but they do not provide specific and clear data, except that in Ukraine there are "default euthanasia" that depends on material remuneration of interested parties [32, p. 40].

It is interesting that according to a survey conducted in October 2011 by the Gorshenin Institute among one thousand respondents from different regions of Ukraine it was found that only $37.1 \%$ of them were against euthanasia. For comparison, in 2007 the number of people who categorically denied euthanasia was $57 \%$ [33, p. 187].

In Ukraine euthanasia is strictly forbidden by law in whatever form it may take place. This is enshrined in Art. 52 of Fundamentals of Ukrainian Health Law [34]: Medical practitioners are prohibited from euthanasia - intentionally speeding up the death or death of a terminally ill patient in order to stop their suffering. Therefore, the person who committed the euthanasia will be prosecuted. It should be noted that in Ukraine there were attempts to legalize passive euthanasia at the legislative level. Thus, the passive form of euthanasia was proposed to be included in the preparation of one of the first editions of the Civil Code of Ukraine. But this idea was not supported and Part 4 of Art. 281 of the Civil Code of Ukraine [35] states that in 
Ukraine it is forbidden to satisfy the request of an individual to terminate his life.

The criminal law of Ukraine, as well as the criminal law of foreign countries, often considers the problem of euthanasia in a broader sense, namely, as the consent of the victim to causing harm. According to the general rule of the Criminal Code of Ukraine [36] such consent of the victim should not be considered as a circumstance which excludes the criminal nature of an act. Therefore, the position of the current legislation of Ukraine on euthanasia is unequivocal - it is a "regular" premeditated murder (without mitigating and aggravating circumstances) qualified under the Art. 115 of the Criminal Code of Ukraine. The motive of compassion is also not mentioned in Art. 66 of the Criminal Code "Circumstances that mitigate punishment" as such. At the same time, the list of mitigating circumstances in the Criminal Code of Ukraine is not exhaustive and the court may, at its discretion, consider other circumstances that are not specified in Art. 66 of the Criminal Code as mitigating circumstances, in particular, the motive of compassion. For example, Art. 61 of the Criminal Code of Russian Federation provides for the motive of compassion as a motive that mitigates punishment [37, p. 146].

An analysis of the criminal law of European countries gives rise to the conclusion that in many of these countries the consent or request of the victim is recognized as a mitigating circumstance. The criminal codes of Germany, Austria, Switzerland, Poland, France, and Lithuania have been drawn up on the principle of referring murder committed at the request of the victim to a murder committed under mitigating circumstances.

A study of the criminal law of the post-Soviet countries shows that in most of them neither the request of the victim nor his consent is a circumstance that excludes or mitigates criminal liability. However, there are some exceptions (for example, in the Criminal Code of Georgia) [38].

\section{CONCLUSIONS}

1. The legalization on euthanasia does not contradict international Acts (Article 3 of the Universal Declaration of Human Rights, Article 6 of the International Covenant on Civil and Political Rights, Article 2 of the Convention for the Protection of Human Rights and Fundamental Freedoms).

2. When committing euthanasia, the person himself consents to the deprivation of his life, so euthanasia cannot be regarded as arbitrary deprivation of another person's life.

3. Approach to distinguish the "right to die" from the natural, inalienable human right - the right to life we consider as unjustified because in fact it is a denial of the most important human rights.

4. We emphasize that only the person (the holder of this right) can make the decision on the disposal of his right to life. No one else can make such a responsible decision and therefore it is impossible to admit the possibility of delegating such a right.
5. We believe that the legalization of euthanasia is only possible in a social, legal state where the issue of palliative care is adequately regulated, ensuring the quality of life of a terminally ill patient and providing psychological support to his/her relatives.

6. However, we insist on inadmissibility to consider a murder committed on the grounds of compassion as a regular murder.

\section{REFERENCES}

1. Case of Pretty v. the United Kingdom (Application no. 2346/02). European Court of Human Rights. 29 April 2002. Available at: http:// hudoc.echr.coe.int/eng?i=001-60448.

2. Manuela Sanles Sanles v. Spain. Report of the Human Rights Committee, U.N. GAOR, 59th Sess., Supp. No. 40, U.N. Doc. A/59/40, Annex X, sect. N, at 505 (0ct. 1, 2004); Available at: http://www.worldcourts.com/

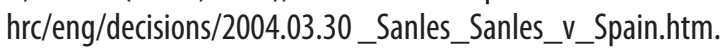

3. Case of Gross v. Switzerland (Application no. 67810/10). European Court of Human Rights. Available at: https://hudoc.echr.coe.int/ eng?i=001-146780.

4. End of life and the European Convention on Human Rights. European Court of Human Rights. May 2019. Available at: https://www.echr.coe. int/Documents/ FS_Euthanasia_ENG.pdf.

5. Declaration of Venice on terminal illness: Adopted by the 35th World Medical Assembly, Venice, Italy, October 1983 and revised by the 57th WMA General Assembly, Pilanesberg, South Africa, October 2006, Available at: https://www.wma.net/policiespost/wma-declaration-of-venice-on-terminal-illness/.

6. WMA Declaration on Euthanasia and Physician-Assisted Suicide: Adopted by the 70th WMA General Assembly, Tbilisi, Georgia, October 2019. Available at: https://www.wma.net/policies-post/declarationon-euthanasia-and-physician-assisted-suicide/.

7. Bugera 0.I. Pidvyshchennya rivnya pravovoyi kul'tury suspil'stva iz vykorystannyam mozhlyvostey merezhi Internet [Increasing the level of the legal culture of society using the possibilities of the Internet]. Aktual'ni problemy vitchyznyanoyiyurysprudentsiyi. 2018. No. 1, 193-196. Available at: http://apnl.dnu.in.ua/1_2018/1_2018.pdf\#page=193.

8. Porter K, Warburton KG. Physicians'views on current legislation around euthanasia and assisted suicide: Results of surveys commissioned by the Royal College of Physicians. Future Hosp J February 1, 2018;5(1):30-34. doi: 10.7861/futurehosp.5-1-30.

9. Singer P. Rethinking of Life and Death. New York: St. Martin's Graffin; $1994,256 \mathrm{p}$.

10. Buchanan J. Unrecognized consequences of assisted suicide legislation better recommendations to improve terminal care. Available at: https://www.parliament.vic.gov.au/images/stories/committees/lsic/ Submissions/Submission_217_-_Dr_John_Buchanan.pdf

11. Huxtable R. Depression and Assisted Dying: Putting the Black Dog to Sleep? In Foster C, Herring J, editors, Depression: Law and Ethics. Oxford University Press. 2017:280-293. doi : https://doi.org/10.1093/ oso/9780198801900.001.0025

12. Koni A.F. K materialam 0 vrachebnoy tayne [To materials on medical confidentiality]. Vrachebnoye delo. Moskva, 1928;6:10. (In Russian).

13. Mathieson SE. Live and Let Die: The Legalisation of Euthanasia in New Zealand. A dissertation submitted in partial fulfilment of the degree of Bachelor of Laws (with Honours) University of Otago October 2013. 64 p. Available at: https://www.otago.ac.nz/law/research/journals/ otag0085109.pdf 
14. Misyura L., Lysenkov M. Lehalizatsiya evtanaziyi: za chy proty [Legalization of euthanasia: for or against]. Visnyk Natsional'noyi akademiyi prokuratury Ukrayiny. 2016;4 (46):98-104.(In Ukrainian).

15. Maleina M.N. Lichnyye neimushchestvennyye prava grazhdan: ponyatiye, osushchestvleniye, zashchita [Personal non-property rights of citizens: concept, implementation, protection]. 2 izd., ispr. i dop. Moskva: MZ-Press, 2001. 243 p. (In Russian).

16. Australian Human Rights Commission. Euthanasia, human rights and the law. May 2016. 47 p.

17. Medical Services (Dying with Dignity) Exposure Draft Bill 2014. The Parliament of the Commonwealth of Australia. Available at: https:// www.aph.gov.au/Parliamentary_Business/Committees/Senate/Legal_ and_Constitutional_Affairs/Dying_with_Dignity/Exposure_Draft.

18. Shariff MJ. Assisted death and the slippery slope - finding clarity amid advocacy, convergence, and complexity. Current Oncology, 2012. 19(3): 143-154.

19. Cohen-Alamgor R. Critical Remarks on the Dutch Policy and Practice of Euthanasia and Proposed Guidelines for Physician-Assisted Suicide (December 11, 2009). From New Medical Ethics to Integrative Bioethics. Ed. Čović A., Gosić N., Tomačević L., eds., Zagreb: Pergamena; 2009, p. 197-216. Available at: https://ssrn.com/abstract=1522045.

20. Jurriaan De Haan. The ethics of euthanasia: Advocates' perspectives. Bioethics 2002;16(2):154-172.

21. Pakhu J. Debate on euthanasia (pros and cons). Dissertação Final sob orientação de: PROF. FAUSTO GOMEZ, O.P., S.Th.D. Universidade católica portuguesa faculdade de teologia mestrado integrado em teologia (1. ${ }^{\circ}$ grau canónico). Lisboa, 2015. 66 p. https://repositorio.ucp.pt/ bitstream/10400.14/18991/1/Joseph\%20Pakhu's\%20Thesis.pdf

22. Vilchyk T.B., Sokolova A. K. Areas for further improvement of legislative regulation of patients' rights in Ukraine. Wiad Lek. 2019;72(7): 1324-1329.

23. Yuridicheskaya otvetstvennost vrachej budet rasti uzhe v etom godu [The legal responsibility of doctors will grow this year. Protocol: legal Internet resource]. 2019 Jan 21. Available at: https://protocol.ua/ ua/yuridicheskaya_otvetstvennost_vrachey_budet_rasti_uge_ v_etom_godu (In Russian).

24. Gornostay A., Ivantsova A., Mykhailichenko T. Medical error and liability for it in some post-soviet countries (Belarus, Kazakhstan, Moldova, Ukraine). Wiad Lek. 2019;72(5 cz 1):877-882.

25. Chekhovska I.V., Balynska 0.M., Blahuta R.I. et al. Euthanasia or palliative care: legal principles of the implementation in the context of the realization of human rights to life. Wiad Lek. 2019;72(4):677-681.

26. Boudreau J.D., Somerville M. Euthanasia and assisted suicide: a physician's and ethicist's perspectives. Medicolegal and bioethics. 2014:4:1-12. doi: http://dx.doi.org/10.2147/MB.S59303.

27. Badarau D.0., De Clercq E., Elger B.S. Continuous Deep Sedation and Euthanasia in Pediatrics: Does One Really Exclude the Other for Terminally III Patients? J Med Philos. 2019 Jan 14; 44(1):50-70. doi: https://doi.org/10.1093/jmp/jhy033.

28. Goligher E., Ely E., Sulmasy D. et al. Physician-Assisted Suicide and Euthanasia in the ICU: A Dialogue on Core Ethical Issues. Crit Care Med. 2017 Feb; 45(2): 149-155. doi: 10.1097/CCM.0000000000001818.

29. Banović B, Turanjanin V. Euthanasia: Murder or Not: A Comparative Approach. Iran J Public Health. 2014 0ct; 43(10):1316-1323. Available at: https://www.ncbi.nlm.nih.gov/pmc/articles/PMC4441884/.

30. Gauthier S., Mausbach J., Reisch T. et al. Suicide tourism: a pilot study on the Swiss phenomenon. J Med Ethics published online August 20, 2014. doi: 10.1136/medethics-2014-102091.
31. Rodriguez C. Euthanasia tourism is the EU encouraging its growth. Forbes. Available at: https://www.forbes.com/sites/ ceciliarodriguez/2019/03/17/euthanasia-tourism-is-the-e-uencouraging-its-growth/\#e28f122229b9.

32. Ishchenko 0.M., Mazyar A.K. Evtanaziya za kryminal'nym zakonodavstvom Ukrayiny [Euthanasia under the Criminal Law of Ukraine] «Molodyy vchenyy», 2017;5.1(45.1);39-41. (In Ukrainian).

33. Rapayeva M.V. Evtanaziya u suchasnomu suspil'stvi ta perspektyvy yiyi dotsil'nosti v Ukrayini [Euthanasia in modern society and its prospects in Ukraine]. Yurydychna nauka, 2014;12:183-190. (In Ukrainian).

34. Osnovy zakonodavstva Ukrayiny pro okhoronu zdorov"ya: Zakon Ukrayiny vid 19 lystopada, 1992 № 2801-XII [Fundamentals of Ukrainian legislation on health care. Law of Ukraine. November 19, 1992, №. 2801-XII]. Available at: https://zakon.rada.gov.ua/laws/show/2801-12.

35. Tsyvil'nyy kodeks Ukrayiny vid 16 sichnya 2003 r. № 435-IV [The Civil Code of Ukraine of January 16, 2003 № 435-IV]. Vidomosti Verkhovnoi Rady Ukrayiny. 2003. 2003;40-44:356. (In Ukrainian).

36. Kryminal'nyy kodeks Ukrayiny vid 5 kvitnya 2001 r. № 2341-III [The Criminal Code of Ukraine of April 5, 2001 № 2341-III]. Vidomosti Verkhovnoi Rady Ukrayiny. 2001. 2001;25-26:131. . (In Ukrainian).

37. Kommentariy k Ugolovnomu kodeksu Rossiyskoy Federatsii / Pod obshch. red. doktora yurid. nauk, Predsedatelya Verkhovnogo Suda RF V.M. Lebedeva. [Commentary on the Criminal Code of the Russian Federation / Under common. ed. doctors jurid. Sciences, Chairman of the Supreme Court of the Russian Federation V.M. Lebedev]. Moskva: Izdatel'stvo NORMA, 2003, 880 p. (In Russian).

38. Criminal code of Georgia, 22 July 1999 № 2287-ES. Available at: https:// matsne.gov.ge/en/document/download/16426/157/en/pdf.

\section{ORCID and contributionship:}

Tetiana A. Pavlenko: 0000-0002-6019-1086

Tetiana Ye. Dunaieva: 0000-0003-3710-1318

Marina Yu. Valuiska: 0000-0002-1355-7436

\section{CORRESPONDING AUTHOR} Tetiana A. Pavlenko

H. S. Scovoroda Kharkiv National pedagogical university

Alchevskyh Street, 29, 61002 Kharkiv, Ukraine

e-mail: pavlenkotatyana7@gmail.com

Received: 13.06 .2019

Accepted: 11.09 .2020

A - Work concept and design, B - Data collection and analysis, C - Responsibility for statistical analysis, $\mathbf{D}$-Writing the article, $\mathbf{E}-$ Critical review, $\mathbf{F}-$ Final approval of the article 